\title{
Recognition and Usage of Sunscreen by Women in Yunnan Province, China
}

\author{
Bo Liu ${ }^{1}$, Sungkwan $\mathrm{An}^{2 *}$ \\ ${ }^{1}$ Department of Beauty Art, Honam University, Gwangju, Korea \\ ${ }^{2}$ Department of Cosmetics Engineering, Konkuk University, Seoul, Korea
}

\author{
"Corresponding author: Sungkwan An, \\ Department of Cosmetic Engineering, \\ Konkuk University, 120 Neungdong-ro, \\ Gwangjin-gu, Seoul 05029, Korea \\ Tel.: +82 24504054 \\ Fax: +82502770227 \\ Email: ansungkwan@konkuk.ac.kr
}

Received May 18, 2021

Revised September 23, 2021

Accepted November 08, 2021

Published December 30, 2021

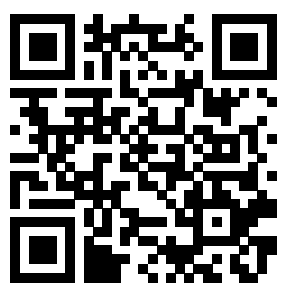

\begin{abstract}
Purpose: In this study, we surveyed 1,325 women ranging in age from 10 s to 40 s and living in Yunnan province, China to examine their awareness regarding the harmfulness of ultraviolet (UV) rays, and their usage and preference of sunscreen. Methods: Questionnaires composed of a total of 22 questions were distributed using the online survey service Wenjuanxing. The data collected were analyzed through frequency analysis and crossover analysis using a statistics program. Results: Awareness that UV rays are harmful to the skin was present in $99.2 \%$ of the subjects. All age groups perceived the harmfulness of UV rays due to the same reasons, which were pigmentation, promotion of premature skin aging, and sunburn. Similarly, all age groups perceived that UV rays are harmful throughout the year. Conclusion: Awareness of the effects of UV rays helps Korean cosmetics companies to market and design sales strategies for sunscreen products in the southern region of China. This survey provided data specific to Yunnan regarding women's preferences, thereby facilitating comparative analysis with other regions in China.
\end{abstract}

Keywords: Sunscreen, Ultraviolet ray, Chinese, Yunnan province, Female

\section{Introduction}

과학기술과 사회의 지속적인 발전과 더불어 환경오염이 갈수록 심 각해지고 있다. 특히 이산화탄소 배출량의 급증으로 인해 오존층이 심각한 파괴를 초래하여 과도한 자외선으로 인한 인체에 미치는 영향 은 갈수록 심각해지고 있다(Liu, 2010). 중국에서도 자외선으로 인한 영향은 동일하게 일어나고 있다. 최근 10 여 년간 중국경제의 급속한 발전으로 사람들의 생활수준이 끊임없이 향상되면서 화장품 사용을 통해 외부 환경에 의한 자극으로부터 피부를 보호하려고 한다(Nan, 2008). 대부분의 여성들은 일반적인 기초화장품 사용뿐만 아니라 기 능성 화장품을 찾는데, 특히 자외선에 대한 인식이 향상됨에 따라 자외선차단제에 대한 요구사항도 끓임없이 늘어나고 있다(Yuan \& Deng, 2009). 글로블 시장조사기관인 민텔(mintel)의 트렌드 분석에 따르면 중국의 자외선차단제 시장은 지속적으로 매년 $10 \%$ 이상씩 증 가하게 될 것으로 전망했다(Deng, 2017).

자외선이 대량으로 인체에 조사되면 자외선에 의해 활성산소종 (reactive oxygen species, ROS)이 과도하게 생산되거나 세포를 구 성하는 유기분자인 단백질, DNA, 지질 등에 산화적 손상을 일으 켜 피부의 광노화를 유발하거나 심하면 암을 야기할 수 있다(Shim, 2021). Fitzpatrick (1988)의 피부 분류 개념에 의한 연구 조사에서 명시한 바와 같이 중국 여성들의 피부 유형은 III 형을 위주로 하고 다음으로 II 형과 IV 형이 그 대부분을 차지한다(Liu et al., 2005). 서양인에 비해 중국여성들은 더 쉽게 햇볕에 타지만 쉽게 일광화상을 받지 않으며 피부암 발생 확률은 서양 사람보다 낮다(Cheng et al., 2007). 하지만 선행연구에 의하면 중국여성들의 자외선에 대한 인식 은 여전히 포괄적이지 못하고 이로 인해 충분한 자외선 차단이 진행 되지 않고 있다(He et al., 2012).

운남성 지역은 연간 및 일일 온도 차이가 작고 건조하고 습한 계절 이며 기온은 지세의 수직높이에 따라 변화가 아주 뚜렷하다(Guo et al., 2004). 또한 이 지역은 고해발, 고자외선 방사지역에 속하기에 사람들은 일반적인 스킨케어 제품보다 자외선차단제를 더 많이 사용 해야 한다(Sun et al., 2011). 하지만 운남성 지역은 경제와 문화가 
상대적으로 낙후할 뿐만 아니라 사람들이 자외선에 대한 인식이 부족 하기에 자외선차단제를 선택하고 구매할 때 경제적으로 고려하거나 또는 허위 홍보로 인해 자외선차단제를 잘못 구매하여 궁극적으로 각 종 피부질병을 초래하기도 한다.

본 연구에서는 중국 운남성 지역을 중심으로 화장품 소비가 가장 많은 10 대-40대 여성들의 자외선 및 자외선차단제에 대한 인식도를 조사하고자 한다. 이를 통하여, 중국의 화장품 소비자들이 자외선의 유해성에 대한 새로운 인식을 갖고 한국처럼 자외선 및 자외선차단제 에 관한 교육 및 홍보 등을 통해 자외선차단제의 중요성을 인식 시키 는 사회적인 분위기를 조성하는데 도움이 되고자 한다. 또한 한국 화 장품 관련 업체가 중국 자외선차단제 시장을 정확히 이해하여 소비자 지향적인 신제품 연구 및 개발이나 영업 마케팅 전략을 수립하는 데 에 실용적인 정보를 제공하는데 도움이 되고자 한다.

\section{Methods}

\section{1. 연구 대상자}

본 연구는 중국 운남성에 거주하는 10 대-40대 여성을 대상으 로 표집하였으며, 조사 기간은 2019년 3월 10일부터 2019년 3월 31 일까지 20 일 간에 걸쳐 진행하였다. 온라인 설문조사 서비스인 Wenjuanxing (Changsha Ranxing Information Technology Co., Ltd, China)을 이용하여 진행하였으며, 총 1,485 부 중에서 성실하게 작성된 1,325 부를 최종 통계 분석에 사용하였다.

\section{2. 설문지의 구성}

본 연구에 사용된 설문지는 고산지대에 위치하여 상대적으로 자외 선 노출량이 많은 중국 운남성 지역에 거주하는 여성의 특성을 반영 하여 구성하였다. 이들의 자외선에 대한 인식, 자외선차단제에 대한 사용 실태, 선호도, 구매 경로 등을 분석하기 위하여 4가지 요인을 설 정하고 22 가지 문항으로 질의하였다. 연령, 최종학력, 자외선 노출 정도, 월평균 수입에 관한 4 가지 인구통계학적 문항과 자외선의 유해 인식과 이로 인한 문제 3 문항, 계절 및 날씨, 실내외에 따른 사용 실 태 문항 3 문항, 자외선차단제에 관한 인식 및 선호도 3 문항, 구매 경 로와 선호도에 관한 7문항으로 구성하였다.

\section{3. 연구 자료 분석}

본 연구를 통해 수집한 데이터는 통계 프로그램인 SPSS Ver. 25 (Statistical Package for Social Science)를 이용하여 분석하였다. 조 사 대상자의 인구통계학적 특성은 빈도분석(frequency analysis)을 실시하였고, 연령별 자외선에 대한 유해성 인지도, 선호도, 사용 실 태 등에 유의미한 차이가 있는지 알아보기 위하여 데이터 코딩(data coding) 후 $\chi^{2}$ 적합도 검증(chi-square goodness of fit test)과 $\chi^{2}$ 독립성 검증(chi-square independence test)을 실행하였다.

\section{Results and Discussion}

\section{1. 연구 대상자의 일반적 특성}

Table 1. Demographic analysis of study subjects

\begin{tabular}{|c|c|c|c|}
\hline Sample & Mean & Frequency (N) & Percentage (\%) \\
\hline \multirow{4}{*}{ Age group } & $<20$ & \multirow{2}{*}{99} & 7.5 \\
\hline & $20-29$ & & 49.9 \\
\hline & $30-39$ & \multirow{2}{*}{498} & 37.6 \\
\hline & $40-49$ & & 5.0 \\
\hline \multirow{4}{*}{ Education } & Junior school graduate & \multirow{2}{*}{122} & 9.2 \\
\hline & High school graduate & & 28.5 \\
\hline & College graduate & \multirow{2}{*}{598} & 45.1 \\
\hline & University graduate & & 17.2 \\
\hline \multirow{4}{*}{ Degree of exposure } & $<1$ hour & 366 & 27.6 \\
\hline & $1-3$ hours & 407 & 30.7 \\
\hline & $3-5$ hours & 424 & 32.0 \\
\hline & $>5$ hours & 128 & 9.7 \\
\hline \multirow{6}{*}{ Average monthly income } & $<$ CNY 2,500 & 389 & 29.4 \\
\hline & CNY $2,500-5,000$ & 532 & 40.2 \\
\hline & CNY 5,000-7,500 & 270 & 20.4 \\
\hline & CNY 7,500-10,000 & 85 & 6.4 \\
\hline & $>$ CNY 10,000 & 49 & 3.7 \\
\hline & Total & 1,325 & 100.0 \\
\hline
\end{tabular}


연구 대상자의 일반적 특성을 빈도 분석한 결과는 Table 1 과 같다. 연령은 20대 미만이 99명(7.5\%), 20대가 661명(49.9\%), 30대가 498 명(37.6\%), 40대가 67 명 $(5.0 \%)$ 으로 나타났고, 최종학력은 중졸 122 명 $(9.2 \%)$, 고졸 377명(28.5\%), 대졸 598명(45.1\%), 대학원졸 228 명 (17.2\%)으로 나타났다. 하루에 햇볕에 노출 정도는 $1 \mathrm{~h}$ 미만 366 명 (27.6\%), $1 \mathrm{~h}-3 \mathrm{~h}$ 정도 407명(30.7\%), $3 \mathrm{~h}-5 \mathrm{~h}$ 정도 424 명(32.0\%), 5 시간 이상 128 명 $(9.7 \%)$ 으로 나타났다.

한 달 평균 수입은 RMB 2,500 이하(한화 약 425,000 원) 389 명(29.4\%), RMB 2,500-5,000 미만(한화 약 425,000-850,000 원) 532 명(40.2\%), RMB 5,000-7,500 미만(한화 약 850,000$1,275,000$ 원) 270 명(20.4\%), RMB 7,500-10,000 미만(한화 약 $1,275,000-1,700,000$ 원) 85 명(6.4\%), RMB 10,000 이상(한화 약 $1,700,000$ 원) 49 명(3.7\%)으로 나타났다.

\section{2. 연령에 따른 자외선의 피부 유해 인식}

\section{1) 자외선의 피부 유해 인식 비교}

자외선의 피부 유해 인식 비교를 연령별로 분석한 결과는 Table 2 과 같다. 10 대는 98 명 $(99.0 \%)$ 이 '예'라고 응답했고, 1 명 $(1.0 \%)$ 이 '아 니오'라고 응답했으며, 20대는 655 명(99.1\%)이 '예'라고 응답했고, 6 명 $(0.9 \%)$ 이 '아니오'라고 응답했다. 30대는 496 명(99.6\%)이 '예'라 고 응답했고, 2 명 $(0.4 \%)$ 이 '아니오'라고 응답했으며, 40 대는 66 명 (98.5\%)이 '예'라고 응답했고, 1 명 $(1.5 \%)$ 이 '아니오'라고 응답했다. 연 령에 따른 자외선의 피부 유해 인식 여부는 통계적으로 유의한 차이 를 보이지 않았다( $p>0.05)$. 이는 연령에 상관없이 모두 자외선이 피 부에 유해하다고 인식한 것으로 나타났다. Kim \& Yoon (2014)은 20-50대 남녀 모두가 자외선이 유해하다고 인식하였는데 이는 본 연구와 비슷한 결과를 나타내었다.
2) 자외선을 유해하다고 인식하는 결정적인 요인 분석

자외선을 유해하다고 인식하는 결정적인 요인에 대해 분석한 결 과는 Table 3 과 같다. 자외선을 유해하다고 응답한 1,315 명만을 대 상으로 어떤 요인으로 인해 유해하다고 인식하는지 후속 질의한 결 과이다. 10대는 37명(37.8\%), 20대는 277명(42.3\%), 30대는 218명 $(44.0 \%), 40$ 대는 28 명 $42.4 \%)$ 이 모두 '색소 침착'을 가장 많이 응답 하였고, 그 다음으로 노화촉진, 일광화상 순으로 유해하다고 인지한 것으로 나타났다. 연령에 따른 통계적 결과, 유의미한 차이가 나타 나지 않았다( $p>0.05)$. 이는 연령에 상관없이 모두 색소 침착으로 인 해 자외선이 유해하다고 인식한 것으로 확인할 수 있다. Park \& Cho (2016)의 연구에서 골프전공학생이 아마추어선수와 프로선수 집단보 다 자외선에 의한 색소침착 기미 주근깨 검버섯 발생에 대해 높은 인 지 수준을 보였고 또한 색소침착 등의 발생 항목이 그을림 현상과 더 불어 자외선의 유해성 인식에 대해 가장 높은 점수를 나타낸 바 이는 본 연구의 연령에 상관없이 색소 침착으로 인해 자외선이 유해하다고 인식한 결과와 비슷한 맥락을 하였다. 또한 Yoon et al. (2011)의 연 구에서 자외선이 피부에 미치는 영향 중 가장 큰 요인으로 색소 침착 으로 응답하여 본 연구와 비슷한 결과를 보였다.

\section{3) 계절별 유해 인식 비교}

계절별 유해 인식 비교한 결과는 Table 4 와 같다. 10 대는 57 명 (57.6\%)이, 20 대는 340 명(51.4\%)이, 30대는 241 명(48.4\%)이, 40 대 는 36 명 $(53.7 \%)$ 이 '일 년 내내'라고 가장 많이 응답한 것으로 나타났 고 통계적으로 유의미한 차이가 나타나지 않았다( $p>0.05)$. 이는 연령 과 상관없이 모두 자외선이 일 년 내내 유해하다고 인지한 것으로 나 타났다.

Table 2. Perception of the harmfulness of UV rays to the skin

Unit: $\mathbf{N}(\%)$

\begin{tabular}{|c|c|c|c|c|}
\hline \multirow{2}{*}{ Variables } & & \multicolumn{2}{|c|}{ Hazard perception N(\%) } & \multirow{2}{*}{$x^{2}(p)$} \\
\hline & & Yes & No & \\
\hline \multirow{5}{*}{ Age group } & $10 \mathrm{~s}$ & $98(99.0 \%)$ & $1(1.0 \%)$ & \multirow{4}{*}{$1.609(0.657$} \\
\hline & $20 s$ & 655 (99.1\%) & $6(0.9 \%)$ & \\
\hline & $30 \mathrm{~s}$ & 496 (99.6\%) & $2(0.4 \%)$ & \\
\hline & $40 \mathrm{~s}$ & $66(98.5 \%)$ & $1(1.5 \%)$ & \\
\hline & Total & $1,315(99.2 \%)$ & $10(0.8 \%)$ & \\
\hline
\end{tabular}

Table 3. Factors for the perception of UV rays as harmful

Unit: $\mathbf{N}(\%)$

\begin{tabular}{|c|c|c|c|c|c|c|}
\hline \multirow{2}{*}{ Variables } & \multicolumn{5}{|c|}{ Factors } & \multirow{2}{*}{$X^{2}(p)$} \\
\hline & Cutaneous cancer & Wrinkle creation & Acceleration of aging & Pigmentation & Sunburn & \\
\hline \multirow{4}{*}{ Age grou } & $7(7.1 \%)$ & $4(4.1 \%)$ & $30(30.6 \%)$ & 37 (37.8\%) & 20 (20.4\%) & \multirow{4}{*}{$14.997(0.242)$} \\
\hline & 77 (11.8\%) & 19 (2.9\%) & 206 (31.5\%) & 277 (42.3\%) & 76 (11.6\%) & \\
\hline & $46(9.3 \%)$ & 27 (5.4\%) & $142(28.6 \%)$ & 218 (44.0\%) & $63(12.7 \%)$ & \\
\hline & $6(9.1 \%)$ & $4(6.1 \%)$ & $21(31.8 \%)$ & $28(42.4 \%)$ & $7(10.6 \%)$ & \\
\hline Total & $136(10.3 \%)$ & 54 (4.1\%) & 399 (30.3\%) & 560 (42.6\%) & $166(12.6 \%)$ & \\
\hline
\end{tabular}




\section{3. 연령에 따른 자외선차단제 인식 비교}

1) 날씨에 따른 사용 여부 비교

날씨에 따른 사용 여부 비교한 결과는 Table 5 와 같다. 비 오는 날 이나 흐린 날에도 자외선차단제를 사용해야 하는지에 대한 질문에 10 대는 76 명 $(76.8 \%)$, 20대는 495명(74.9\%), 30대는 358명(71.9\%), 40 대는 56 명 $(83.6 \%)$ 이 '예'라고 가장 많이 응답하여 20대의 인식도가 가장 높게 나타났다. 연령별로 날씨에 따른 자외선차단제 사용 여부 는 통계적으로 유의한 차이가 나타나지 않았다( $p>0.05)$. 이는 연령에 상관없이 모두 날씨에 영향을 받지 않고 사용하고 있는 것으로 보인 다. Rhie \& Im (2013)의 연구에서 비오는 날이나 흐린 날의 자외선 차단제품 인식도는 30 대의 인식도가 가장 높은 것으로 나타내어 본 연구와는 차이가 있다.

\section{2) 실내에서 자외선 차단제 사용 현황 조사결과}

실내에서 자외선 차단제 사용 여부에 대한 결과는 Table 6 와 같이 10 대는 54 명 $(54.5 \%), 20$ 대는 385 명 $(58.2 \%)$, 30대는 245 명(49.2\%), 40 대는 39 명 $(58.2 \%)$ 이 '예'라고 가장 많이 응답하여 모든 연령층에서 평균 $54.6 \%$ 의 여성이 실내에서도 자외선차단제를 사용해야 한다고
응답했다. 연령별로 실내에서 자외선차단제 사용 여부는 통계적으로 유의미한 차이를 보였으며 $(p<0.05), 10$ 대부터 30 대까지는 자외선차 단제를 사용하지 않아도 된다고 응답한 비율이 두 번째로 높게 나타 난 반면에, 40 대는 '잘 모르겠다'는 응답이 두 번째로 높게 나타났다. Rhie \& $\operatorname{Im}$ (2013)은 실내에서의 자외선 차단제품 사용은 연령이 높 을수록 자외선 차단제품을 사용해야 한다고 인식하고 있는 것을 나타 내어 본 연구와 비슷한 결과를 나타내었다.

3) 특정 계절에 따른 사용 여부 비교

특정 계절에 따른 사용 여부에 비교를 살펴본 결과는 Table 7 와 같 다. 4 계절 중에서 여름을 제외한 나머지 계절에도 자외선차단제를 사 용해야 되는지 묻는 설문의 응답을 비교한 결과이다. 10 대는 94 명 (94.9\%), 20대는 589명(89.1\%), 30대는 432명(86.7\%), 40대는 58명 (86.6\%)이 '예'라고 가장 많이 응답한 것으로 나타났다. 연령별로 특 정 계절에 따른 자외선차단제 사용 여부는 통계적으로 유의미한 차이 가 없었다 $(p>0.05)$. 이는 연령에 상관없이 모두 4계절 내내 자외선차 단제를 사용해야 한다고 인지한 것으로 나타났다. Rhie \& $\operatorname{Im}(2013)$ 는 20대, 30 대, 40 대 모두 자외선 차단제를 매일 사용하는 사람이 많

Table 4. Comparison of hazard perceptions based on seasons

Unit: $\mathbf{N}(\%)$

\begin{tabular}{|c|c|c|c|c|c|c|c|}
\hline \multirow{2}{*}{ Variables } & \multicolumn{5}{|c|}{ Seasons } & \multirow[b]{2}{*}{ No } & \multirow{2}{*}{$X^{2}(p)$} \\
\hline & Spring & Summer & Autumn & Winter & All the time & & \\
\hline \multirow{4}{*}{ Age grour } & 5 (5.1\%) & 29 (29.3\%) & $2(2.0 \%)$ & $3(3.0 \%)$ & 57 (57.6\%) & $3(3.0 \%)$ & \multirow{4}{*}{$22.001(0.108)$} \\
\hline & $29(4.4 \%)$ & 235 (35.6\%) & $9(1.4 \%)$ & $31(4.7 \%)$ & 340 (51.4\%) & $17(2.6 \%)$ & \\
\hline & 20 (4.0\%) & 167 (33.5\%) & $9(1.8 \%)$ & $44(8.8 \%)$ & 241 (48.4\%) & 17 (3.4\%) & \\
\hline & $3(4.5 \%)$ & 17 (25.4\%) & $4(6.0 \%)$ & $5(7.5 \%)$ & $36(53.70 \%)$ & $2(3.0 \%)$ & \\
\hline Total & 57 (4.3\%) & 448 (33.8\%) & $24(1.8 \%)$ & $83(6.3 \%)$ & 674 (50.9\%) & 39 (2.9\%) & \\
\hline
\end{tabular}

Table 5. Comparison of availability according to the weather

Unit: $\mathbf{N}(\%)$

\begin{tabular}{|c|c|c|c|c|c|}
\hline \multirow{2}{*}{ Variables } & & \multicolumn{3}{|c|}{ Availability according to the weather } & \multirow{2}{*}{$X^{2}(p)$} \\
\hline & & Yes & No & I don't know & \\
\hline \multirow{4}{*}{ Age group } & $10 \mathrm{~s}$ & $76(76.8 \%)$ & $16(16.2 \%)$ & $7(7.1 \%)$ & \multirow{4}{*}{$8.244(0.221)$} \\
\hline & $20 \mathrm{~s}$ & 495 (74.9\%) & $97(14.7 \%)$ & $69(10.4 \%)$ & \\
\hline & $30 \mathrm{~s}$ & $358(71.9 \%)$ & $72(14.5 \%)$ & $68(13.7 \%)$ & \\
\hline & $40 \mathrm{~s}$ & $56(83.6 \%)$ & $6(9.0 \%)$ & $5(7.5 \%)$ & \\
\hline \multicolumn{2}{|c|}{ Total } & $985(74.3 \%)$ & $191(14.4 \%)$ & 149 (11.2\%) & \\
\hline
\end{tabular}

Table 6. Indoor use status

\begin{tabular}{llrcrl}
\hline \multirow{2}{*}{ Variables } & & \multicolumn{3}{c}{ Whether to use sunscreen indoor } & \multirow{2}{*}{$X^{2}(p)$} \\
\cline { 3 - 5 } & & Yes & No & I don't know & \\
Age group & $10 s$ & $54(54.5 \%)$ & $33(33.3 \%)$ & $12(12.1 \%)$ & \\
& $20 s$ & $385(58.2 \%)$ & $197(29.8 \%)$ & $57(11.4 \%)$ & $24.797(0.000)$ \\
& 30s & $245(49.2 \%)$ & $196(39.4 \%)$ & $16(23.9 \%)$ & \\
& Tos & $39(58.2 \%)$ & $12(17.9 \%)$ & $164(12.4 \%)$ \\
\hline
\end{tabular}


이 나타나 본 연구와 같은 맥락을 제시하였다.

\section{4) 자외선차단제 사용에 대한 적정 시작 시기 비교}

자외선차단제 사용에 대한 적정 시작 시기를 살펴본 결과는 Table 8 와 같다. 10 대는 '성인 이후'가 29 명(29.3\%)으로 가장 높게 나타 났고, 그 다음은 '고등학생'이 28명(28.3\%)으로 보인다. 20대는 '성 인 이후'가 215 명(32.5\%)으로 가장 높게 응답했고, 그다음은 '고등 학생'이 169명(25.6\%)으로 나타났다. 30대는 '성인 이후'가 187명 (37.6\%)으로 가장 높게 확인할 수 있었고, 그다음은 '고등학생'이 131 명(26.3\%)으로 나타났다. 40대는 '성인 이후' 및 '중학생'이 각 16 명 (23.9\%)으로 나타났다. 연령별로 자외선차단제 사용에 대한 적정 시 작 시기 여부는 통계적으로 유의미한 차이가 있는 것으로 확인할 수 있으며 $(p<0.05), 10$ 대와 20 대, 30 대는 성인 이후 쓰는 것이 적정하 다고 응답했으나, 40 대는 중학생과 성인 이후에 쓰는 것이 적정하다 고 응답한 비율이 동일하게 나타났다. Kim \& Yoon (2014)의 논문에 서 남녀모두 자외선차단제 최초사용 나이는 17-19세가 각각 $61.1 \%$, $51.8 \%$ 로 가장 높게 나타나서 본 연구에서 제시한 자외선차단제 사용 적정 시작 시기가 더 빠른 것을 알 수 있다.

\section{Conclusion}

본 논문에서는 지리적으로 중국 남부에 위치하고 미얀마, 라오스, 베트남 등 3 개 국과 국경을 접하고, 기후적으로 동남아 특유의 열 대성 기온을 보이는 고산지대인 운남성에 거주하는 10-40대 여성 1,325 명을 대상으로 자외선 및 자외선의 유해 인식 정도, 자외선차단
제의 사용 실태 및 선호도 조사를 통해 연령별 교차 분석으로 어떠한 특징을 보이는지 분석하였다. 이를 통해 한국 화장품 기업의 중국 남 부지역 진출 시 자외선차단 제품의 마케팅 및 영업 전략을 돕고, 중 국 각 지역별 여성의 선호도에 있어 운남성 만의 기초 자료를 제공함 으로써 타 지역과의 비교분석을 용이하게 하는데 그 의의가 있으며, 최종결론은 다음과 같다.

설문에 참여한 $99.2 \%$ 의 여성은 자외선이 피부에 유해하다는 인식 을 가지고 있으며, 모든 연령층에서 동일하게 색소침착, 노화촉진, 일광화상 순의 사유로 유해하다고 인지한 것으로 나타났다. 이것으 로 미루어 보아 아시아계 여성의 스킨케어 주관심사인 기미, 주근깨, 잡티와 같은 색소 침착 케어를 접목한 2 중 기능성 자외선 차단제의 수요도 계속해서 증가할 수 있을 것으로 사료된다. 특정 계절에서 자 외선이 더 유해하다고 보는지 후속 질의한 결과, 모든 연령층에서 일 년 내내 자외선이 유해하다고 인식하였고, 자외선차단제를 사용함에 있어서 날씨가 영향을 끼치는지 확인하기 위하여 비오는 날이나 흐린 날에도 자외선차단제를 사용해야 하는지 묻는 질문에는 $74.3 \%$ 의 여 성이 '예'라고 응답하여 자외선의 유해성에 상당히 높은 수준의 인식 을 가지고 있는 것으로 나타났다.

실내에서 자외선차단제의 사용 여부를 묻는 질문에서 연령 별 통 계적 유의미한 차이가 나타났는데( $p<0.05), 10$ 대부터 30대까지는 모 두 실내에서 자외선차단제를 사용하지 않아도 된다고 응답한 비율이 두 번째로 높게 나타난 반면에, 40 대는 잘 모르겠다는 응답이 두 번 째로 높게 나타났다. 그러나 모든 연령층에서 평균 $54.6 \%$ 의 여성이 실내에서도 자외선차단제를 사용해야 한다고 응답했고, 여름이 아닌 다른 계절에도 $88.5 \%$ 의 여성이 자외선차단제를 사용해야 한다고 응 답한 것으로 나타났다. 자외선차단제를 바르기 시작하는 적정한 시

Table 7. Comparison of availability according to specific seasons

Unit: N (\%)

\begin{tabular}{|c|c|c|c|c|c|}
\hline \multirow{2}{*}{ Variables } & & \multicolumn{3}{|c|}{ Availability according to specific seasons } & \multirow{2}{*}{$X^{2}(p)$} \\
\hline & & Yes & No & I don't know & \\
\hline \multirow{4}{*}{ Age group } & $10 \mathrm{~s}$ & $94(94.9 \%)$ & $4(4.0 \%)$ & $1(1.0 \%)$ & \multirow{4}{*}{$9.277(0.159)$} \\
\hline & $20 \mathrm{~s}$ & 589 (89.1\%) & $51(7.7 \%)$ & $21(3.2 \%)$ & \\
\hline & $30 \mathrm{~s}$ & $432(86.7 \%)$ & $46(9.2 \%)$ & $20(4.0 \%)$ & \\
\hline & $40 \mathrm{~s}$ & $58(86.6 \%)$ & $4(6.0 \%)$ & $5(7.5 \%)$ & \\
\hline \multicolumn{2}{|c|}{ Total } & $1173(88.5 \%)$ & 105 (7.9\%) & 47 (3.5\%) & \\
\hline
\end{tabular}

Table 8. Comparison of appropriate start times for sunscreen use

Unit: $\mathbf{N}(\%)$

\begin{tabular}{|c|c|c|c|c|c|c|c|}
\hline \multirow[b]{2}{*}{ Variables } & \multicolumn{5}{|c|}{ Appropriate start times for sunscreen use } & \multirow[b]{2}{*}{ After adult } & \multirow[b]{2}{*}{$X^{2}(p)$} \\
\hline & Newborn & Infant & $\begin{array}{l}\text { Elementary } \\
\text { student }\end{array}$ & $\begin{array}{l}\text { Middle school } \\
\text { student }\end{array}$ & $\begin{array}{l}\text { High school } \\
\text { student }\end{array}$ & & \\
\hline \multirow{4}{*}{ Age grou } & $3(3.0 \%)$ & $5(5.1 \%)$ & $10(10.1 \%)$ & $24(24.2 \%)$ & $28(28.3 \%)$ & $29(29.3 \%)$ & \multirow{4}{*}{$22.001(0.108)$} \\
\hline & $47(7.1 \%)$ & $30(4.5 \%)$ & $58(8.8 \%)$ & $142(21.5 \%)$ & $169(25.6 \%)$ & $215(32.5 \%)$ & \\
\hline & $21(4.2 \%)$ & $35(7.0 \%)$ & $28(5.6 \%)$ & $96(19.3 \%)$ & $131(26.3 \%)$ & $187(37.6 \%)$ & \\
\hline & $3(4.5 \%)$ & $11(16.4 \%)$ & $8(11.9 \%)$ & $16(23.9 \%)$ & $13(19.4 \%)$ & $16(23.9 \%)$ & \\
\hline Total & $74(5.6 \%)$ & $81(6.1 \%)$ & $104(7.8 \%)$ & $278(21.0 \%)$ & $341(25.7 \%)$ & 447 (33.7\%) & \\
\hline
\end{tabular}


기를 묻는 질문에서는 모든 연령에서 성인 이후부터가 적정하다고 응 답했고, 영유아가 적정하다고 응답한 비율은 $11.7 \%$ 에 불과하여, 자 외선의 유해성과 자외선차단제의 필요성은 높게 인식하고 있으면서 도 자외선차단제의 사용은 성인 이후부터 쓰는 것이 좋다는 인식이 있어 이를 근거로 영유아 전용 자외선차단제의 시장 규모를 키우기 위해서는 영유아들도 자외선차단제를 필요로 한다는 내용의 소비자 계몽이 선행되어야 한다는 것을 알 수 있었다.

본 연구자는 본 논문을 토대로 후속 연구에도 중국 여성의 자외선 차단제에 대한 구매 선호도 및 선택 요인을 연구를 지속하고자 하며', 한국 화장품 관련 업체가 중국 자외선차단제 시장을 정확히 이해하여 소비자 지향적인 신제품 연구 및 개발이나 영업 마케팅 전략을 수립 하는 데에 실용적인 정보를 제공할 수 있는 것을 기대한다.

This work is a part of the Bo Liu's M.S. thesis at the Konkuk University, Seoul, Korea.

\section{Author's contribution}

B.L. and S.K.A. contributed equally to this work. B.L. collected SAXS data. S.K.A. oversaw the project, and contributed to all aspects of analysis and experimental design. B.L. wrote the manuscript with assistance from S.K.A.

\section{Author details}

Bo Liu (Professor), Department of Beauty Art, Honam University, \#120, Honamdae-gil, Gwangsan-gu, Gwangju 62399, Korea ; Sungkwan An (Professor), Research Institute for Molecular-Targeted Drugs, Department of Cosmetic Engineering, Konkuk University, 120 Neungdong-ro, Gwangjin-gu, Seoul 05029, Korea.

\section{References}

Cheng SW, Cao M, Liu F, Liu CL, Tong CG, Zhang XY, He YL. Investigation of skin phototypes 680 cases of beijing female population. Chinese Journal of Dermatology, 40: 114-115, 2007.

Deng J. Current situation of suncare market. Detergent \& Cosmetics, 3: 34-40, 2018.

Fitzpatrick TB. The validity and practicality of sun-reactive skin types i through VI. Archives of Dermatology, 124: 869-871, 1988.
Guo SC, Chang YL, Hu F, Zhang XN, Li D. Numerical study for influence of latitude and ailtitude on surface biologicallyactive UV irradiance in Yunnan region. Yunnan Geographic Environment Research, 16: 10-13, 2004.

He RJ, Ma LP, Dong LP, Lai DH, Chen SW. A questionnaire-basee study on sun- exposure knowledge and protection behavior in women from North China. Ningxia Medical Journal, 34: 1256-1258, 2012.

Kim MY, Yoon CS. The research on the ultraviolet protector recognition of the adult and propensity to consume. Journal of Beauty Industry, 8: 63-84, 2014.

Lee YK, Kim JD. Influence of sun-expose on the skin aging. Journal of the Korean Society of Cosmetology, 13: 841-850, 2007.

Park SM, Cho SW. The effect of golf major's awareness on harmfulness of UV and skin \& health care behavior on selfesteem. Asian Journal of Beauty and Cosmetology, 14: 4256, 2016.

Liu LH. Application status and prospect of cosmetics of UV protection. Chemical Technology Market, 33: 25-27, 2010.

Liu W, Lai W, Wang XM, Li L, Tian Y, Lu Y, U YY, Li Y, Zhang P, Wu Y, Chen L. Investigation of skin phototypes of Chinese female population. Journal of Clinical Dermatology, 34: 420-423, 2005.

Nan HM. Situation and developing trends of sun care products market. Detergent \& Cosmetic, 31: 35-39, 2008.

Rhie SJ, Im JM. A study on the awareness for the use of ultraviolet ray protective products and the actual state of their use based on age and gender. Journal of Investigative Cosmetology, 9: 129-136, 2013.

Shim JH. Anti-aging effects of ganoderol A in UVA-irradiated normal human epidermal keratinocytes. Asian Journal of Beauty and Cosmetology, 19: 57-64, 2021.

Sun DJ, Tu Y, Nong X, Li JL, He L. Clinical analysis of 110 cases of cosmetic dermatoses in Kunming area. Journal of Clinical Dermatology, 40: 70-72, 2011.

Yoon JS, Kim SR, Cho HK, Hong SH. A study on awareness of college students on ultraviolet radiation and their usage of sunscreen in Chung-cheong area. Journal of the Korean Society of Beauty and Art, 12: 187-198, 2011.

Yuan LM, Deng DQ. The property and application of sunscreen. Journal of Dermatology and Venereology, 31: 20-23, 2009. 


\section{국문초록}

\section{중국 운남성 여성의 자외선차단제에 대한 인식 및 사용 실태 연구}

유보 ${ }^{1}$, 안성관 ${ }^{2 *}$

${ }^{1}$ 호남대학교 뷰티미용학과, 광주, 한국

${ }^{2}$ 건국대학교 화장품공학과, 서울, 한국

목적: 본 연구에서는 중국 운남성 지역을 중심으로 화장품 소비가 가장 많은 10 대 -40 대 여성들이 자외선 및 자외선차단제에 대 한 인식도와 사용 실태, 구매 경로 등을 조사하고자 한다. 방법: 온라인 설문조사 서비스인 Wenjuanxing (Changsha Ranxing Information Technology Co., Ltd, China)을 이용하여 총 22문항으로 구성된 설문지를 배포하여 수집된 자료를 통계 프로그램을 이 용하여 빈도분석 및 교차분석을 실시하였다. 결과: 설문에 참여한 $99.2 \%$ 의 여성은 자외선이 피부에 유해하다는 인식을 가지고 있 으며, 모든 연령층에서 동일하게 색소침착, 노화촉진, 일광화상 순의 사유로 유해하다고 인지한 것으로 나타났다. 결론: 본 연구는 중국 남부 지역으로 진출을 희망하는 한국 화장품 기업이 자외선차단제를 기획할 때 참고할 수 있는 기초 자료를 제공하였다는 점 에서 상당한 의의가 있다고 판단된다.

핵심어: 자외선차단제, 자외선, 중국, 운남성, 여성

\section{참고문헌}

김미영, 윤친성. 성인의 자외선차단제 인지도와 소비성향에 관한 연구. 뷰티산업연구, 8: 63-84, 2014.

박선민, 조상우. 골프전공자의 자외선 유행성 인식 및 피부건강관리행동이 자아존중감에 미치는 영향. 아시안뷰티화장품학 술지, 14: 42-53, 2016.

심중현. 자외선 조사에 의해 노화된 인간각질형성세포에서 Ganoderol A의 항노화 효능. 아시안뷰티화장품학술지, 19: 57-64, 2021.

윤지성, 김선예, 조혜경, 홍송희. 충청지역 남녀 대학생의 자외선에 대한 인지도와 자외선차단제 이용실태에 관한 연구. 한 국인체미용예술학회지, 12: 187-198, 2011.

이승자, 임정미. 연령과 성별에 따른 자외선 차단제품 사용에 관한 인식도와 제품 이용 실태에 관한 연구. 대한미용학회 지,19: 129-136, 2013. 


\section{中文摘要}

\section{中国云南省女性对防晒霜的认识和使用状态}

刘博 ${ }^{1}$, 安晟官 ${ }^{2^{*}}$

${ }^{1}$ 湖南大学美容学科, 光州, 韩国

²建国大学化妆品学科, 首尔, 韩国

目的: 在这项研究中, 我们对居住在中国云南省的 1,325 名年龄在 10 到 40 岁之间的女性进行了调查, 以了解她们 对紫外线 (UV)的危害认识, 以及她们对防晒霜的使用和偏好。方法: 使用在线调查服务文卷兴分发共 22 个问题 的问卷。使用统计程序通过频率分析和交叉分析对收集的数据进行分析。结果: $99.2 \%$ 的受试者意识到紫外线对 皮肤有害。由于相同的原因, 所有年龄组都感受到紫外线的危害, 即色素沉着、促进皮肤过早老化和晒伤。同 样, 所有年龄段的人都认为紫外线一年四季都是有害的。结论: 对紫外线影响的认识有助于韩国化妆品公司在中 国南方地区营销和设计防晒产品的销售策略。本次调查提供了云南特有的女性偏好数据, 便于与中国其他地区 进行比较分析。

关键词: 防晒霜, 紫外线, 中国人，云南省，女性 